\title{
IMAGINARY LANDSCAPES - OR IS THE TRUTH OUT THERE? DYNAMICS IN LANDSCAPE REPRESENTATIONS IN RELATION TO 'REAL' LANDSCAPES ON SAAREMAA ISLAND, ESTONIA
}

\author{
Helen Sooväli-Sepping ${ }^{1}$, Egle Kaur \& Hannes Palang
}

Received 2 December 2009; Accepted 10 June 2010

\begin{abstract}
The emergence of a particular future landscape, among the numerous potential landscapes, depends on policy options, on prevailing attitudes in society, and on cultural values. This is particularly the case for the countries that have recently joined the European Union - specifically the implementation of new policies has changed the function of the rural countryside significantly. In an empirical illustrative case we discuss the change in values on landscape and the conflicting attitudes to landscape in the society on Saaremaa Island (Estonia) in the $20^{\text {th }}$ century. As a background explanation we present the dynamics of the physical landscape and explore the reasons for changes. We then move on to multiple perspectives of how the landscape has been represented in the past as well as today and perceived by different interest groups. Based on that, we finally argue that landscape representations differ from the physical landscape and discuss whether contemporary landscape policy decisions support the actual situation or rather the historical visual imagery.
\end{abstract}

Keywords: demographic behaviour, rural and urban population, natality, mortality, marriage, divorce, sex and age structure, religion, ethnic, education structure of population

\begin{abstract}
Abstraktne: Maastike tulevik sõltub muuhulgas poliitilistest otsustest, ühiskonnas valdavatest hoiakutest ja kultuurilistest väärtustest. See mõju avaldub iseäranis selgesti hiljuti Euroopa Liiduga liitunud maades, kus uute poliitikate rakendumine on maapiirkondade talitlust märgatavalt muutnud. Käesoleva artikli huvifookuses on füüsilise maastiku ja maastiku representatsioonide vahekord, mida uurimuse empiirika osa lahkab maastikke puudutavate väärtushinnangute ning hoiakute kaudu 20. sajandi Saaremaal. Selle taustaks on esitatud maastikumuutuste dünaamika ning muutuste põhjused. Uuritud representatsioonid väljendavad selgelt maastikke puudutavate arvamuste paljusust ning maastiku representatsiooni ja tegelikkuse lahknevust. Selle põhjal tõstatub küsimus, kas tänased maastikupoliitilised otsused toetavad reaalsust või pigem minevikku suunatud kuvandit Saaremaast.
\end{abstract}

Võtmesõnad: maastik, representatsioon, dünaamika, hoidmine

\footnotetext{
${ }^{1}$ Centre for Landscape and Culture, Estonian Institute of Humanities, Tallinn University, Uus-Sadama 5, Tallinn, Estonia, E-mail: helen.soovali@tlu.ee
} 


\section{Introduction}

This paper deals with the relationship between physical landscapes and visual landscape representations. The relationship is studied from a dualistic perspective as landscape representations and actual landscapes are mutually dependent. Olwig (2004) sees the relationship between the real landscape and representation as circular, as the particular form of representation can shape the landscape represented, and the landscape represented can shape its representation. "This circularity, furthermore, can end in a form of self-referential circulating reference in which the landscape is shaped in its own representational image, and the distinction between representation, and that is represented, is lost" (Olwig, 2004: 42). The key to uncovering the myths, the representations, and the discourses on land and landscapes, as Widgren (2004) has argued, rests not only in the representations, but in the land itself. Therefore, we allege that possible reasons for staticity and/or dynamics in the actual physical landscapes could be found in investigating landscape representations, and vice versa. Studying these relationships allows for an applied perspective for managing landscapes and gives insight for planners into the preparation of future landscapes. The primary aim of our paper is to examine the landscape imagery in transition, and thereby also to determine the differences and similarities of the landscape imagery and the physical landscape.

The dominant way of handling landscape conceptually and empirically in cultural geography is through its representational practice and the socio-cultural molding of the environment (entries 'cultural landscape' and 'landscape' in Castree \& McMillan, 2004; Dictionary of Human Geography, 2009; Dorrian \& Rose, 2003; Gallent \& Andersson, 2007; Mitchell, 2002). Read (2005) has in her works pointed out the tension between the rural environment as the lived experience of those who dwell within it and, the objectification of that environment as scenery by those who visit it. Theoretical discussions in landscape studies have emphasized the need to find means for engaging both the symbolic and the empirical aspects of landscape research. Keisteri (1990), Jones (1991) and Cosgrove (1998, 2003; 2008) among others support the idea that natural and cultural landscapes are not opposites, rather different layers of the landscape. In that way we focus upon environmental, social, cultural, aesthetic, and economic issues simultaneously as exemplified in the works of Akbar et al. (2003), Claval (2004), Daugstad \& Grytli (1999), Egoz et al. (2001), Jones (2004) and Setten (2001, 2002).

The character of Saaremaa, both in terms of natural conditions as well as historical and cultural development makes it a worthy location for studying landscape transformation and change in cultural values. For visitors who live on the mainland, islands tend to represent something that is distant to them - exciting and exotic from the commonplace. A landscape of wooded meadows, pristine coastline and dispersed farmsteads is the image currently perceived as typical of an Estonian island, particularly Saaremaa. Earlier studies on Saaremaa (Kaur et al., 2004; Sooväli et al., 2004) on the perception of the island's character share similarities in the opinions. In general terms, the opinions of the local people, county officials, and the national media expressed that distinct landscape of Saaremaa lays in its juniper shrubberies, purity and characteristics of nature, coastal areas, the island's geographical isolation, stone fences, cliffs, semi-natural plant communities and medieval churches. The dangers concerning the island's environment are associated with real estate development, booming tourism, careless forest felling and the construction of the deep-water harbor.

Schoolchildren visit Saaremaa as part of their school curriculum; studies show the island is among their topmost landscape preferences (Palang, 1993). Saaremaa is a favored place to spend summer weekends with family and friends as domestic tourism has increased within Estonia. Foreign tourists have discovered the charm of the island and are among those who holiday there. To Nordic tourists, the island, with its rustic features, is perceived as having maintained the character of the Scandinavian summer landscapes of childhood from the 1930s1950s (Snellman, 2000; Assmuth, 2001). Since Saaremaa is a hotspot for visitors, the landscapes of Saaremaa are under pressure. Various interest groups have expectations and interests - aesthetic, recreational and economic - in the landscapes on the island and thus the landscapes of Saaremaa are an arena of conflicting interests. 


\section{Saaremaa in facts: dynamics in demography and land use change}

The study area is the Estonian island of Saaremaa (see Figure 1), also known as Ösel in Swedish and German. With an area of $2,673 \mathrm{~km}^{2}$, it is one of the largest islands in the Baltic Sea and is as of 2008 home to 36,280 residents.

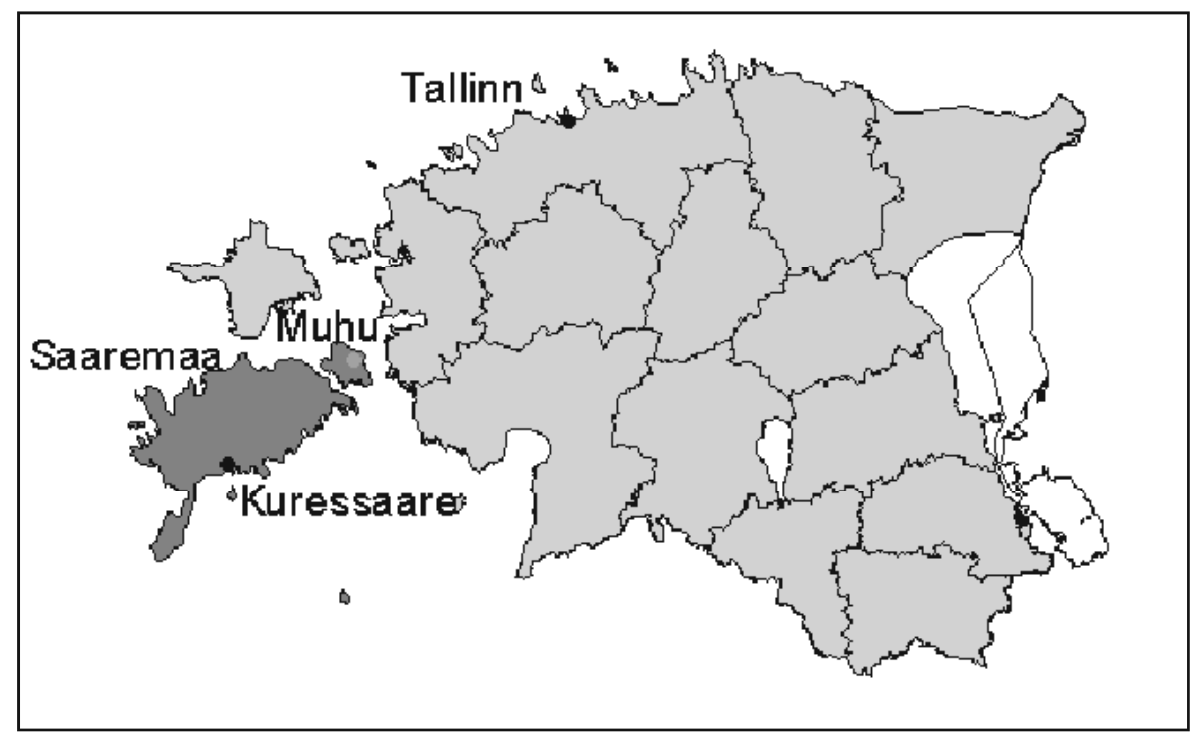

Fig 1. Location of case study area Saaremaa Island

The $20^{\text {th }}$ century saw major changes in the population of the Saaremaa Island. The population of the island was at its apex in the beginning of the century, when it reached 58,000 (1922). The island was a typical agrarian region with high population density and abundance of villages. Before World War II around 10,000 farmsteads were counted on the island with the average size being 23 hectares. The years 1941-1950 witnessed drastic decrease in population. The war forced numerous islanders to migrate to the West as there were severe battles on Saaremaa. Even more people were forced to leave the island before the war because of large scale Soviet deportations in 1941 and 1949 and establishment of Soviet border zone in coastal areas. As a result, entire villages in some parts of the island were deserted and left looking like "ghost" villages, with empty homesteads in the landscape for many decades. From the second half of the $20^{\text {th }}$ century Saaremaa's population has increased 1.8 times in the core of the island, whereas on East Saaremaa it has decreased twice and on West Saaremaa 3.6 times respectively. The numbers will continue to decrease (Marksoo, 2002).

As the demographic and political situation on Saaremaa changed in the 20th century, so did land use. The loss of population, as well as the Soviet centralization and collectivization of agriculture, resulted in abandonment of the traditional structures of the island's agrarian society. By the early 1950s, the state-owned collective farms, with an average size of 567 hectares, had replaced private farms; in the middle of the 1980s, the agricultural production had reached its maximum capacity and, on average, each of the 15 collective farms of Saaremaa took up around 13,000 hectares. After Estonia regained independence, the number of large-scale agricultural collectives declined critically and although private farming was re-established in early 1990s, agricultural activity has remained marginal on the island.

According to official statistics (Eesti Statistika..., 2001) and land use studies (Palang et al., 1998), $88 \%$ of the island was in agricultural use (i.e. pastures, arable land, hay meadows, gardens) in 1918, while in the beginning of the 21st century (2001) this figure has declined drastically to $17 \%$ (see Table 1 and Figure 2). Consequently, the habitual open landscape with semi-natural meadows, to a large extent, has turned into land covered with overgrowth and it looks considerably different of what people consider typical landscape of Saaremaa. We argue that with the large scale changes the general traditional expression of Saaremaa's regional character with open views and agricultural land-use pattern is lost. At the same time, continuity in landscape is not expressed only in the large scale but also in the small features that people tend to assign memory assistants, incorporated into people's identity and that have heritage 
value, as argued by Maandi $(2005,2009)$. A careful viewer may trace a few renovated reedthatched farmhouses (some of them turned into guesthouses and local open-air museums like Mihkli Farm Museum in Viki village) or farmhouses that have been rebuilt in the interpretive style of vernacular architecture, windmills and stone fences, most of them renovated or newly built with the support schemes of Ministry of Environment and Ministry of Agriculture. In recent years, relatively large amounts of land have been sold to foreigners, primarily to summer visitors from Finland. The Finnish countryside architecture differs from that of Estonia and thereby it changes the character of the landcape to some extent. Moreover, it has become fashionable among Estonian second-home dwellers to buy similar houses; the Finnish mökki-cottages as they are regarded as ideal country houses. This "Nordic ideal", regarded as a symbol of welfare, has, with the help of popular country-life magazines, become a popular trend to follow among numerous Estonian dwellers (see also Palang et al., 2000).

However, admitting, that without historic landscape analysis (see e.g. Rippon, 2004) it is intricate to assess the landscape character of Saaremaa, we presume that the pre-WWII landscape appearance has changed radically, caused by the dramatic changes in demographic situation and agricultural re-organization.

$\begin{array}{rrrrrrrrrr}\text { YEAR } & 1918 & 1929 & 1939 & 1942 & 1945 & 1966 & 1975 & 1986 & 1992 \\ \% & 88,05 & 69,22 & 69,6 & 73,16 & 70,69 & 37,5 & 32,7 & 30,5 & 30,53\end{array}$

Tab 1. Dynamics of the share of agricultural land on Saaremaa in per cents

1900
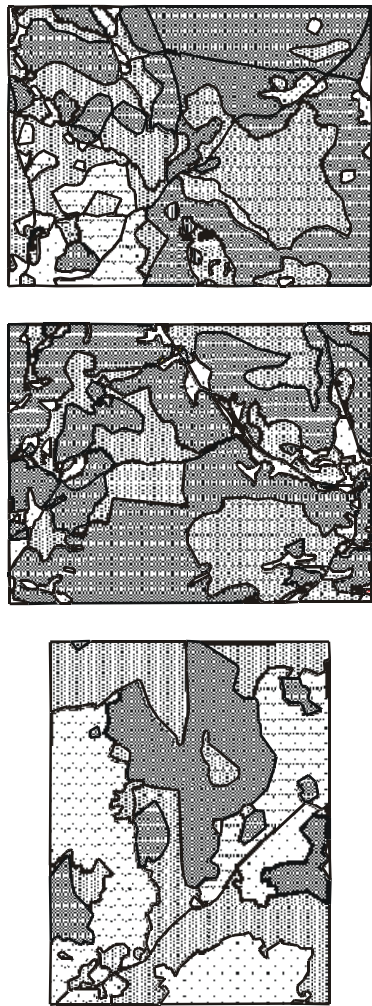

1960
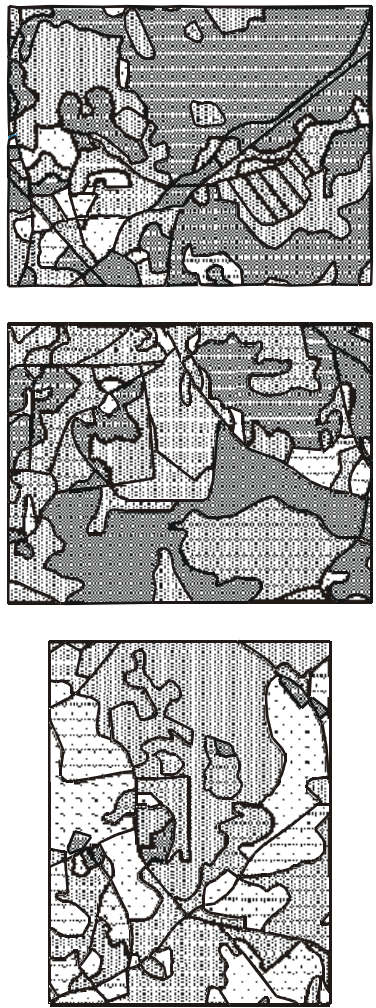

1990
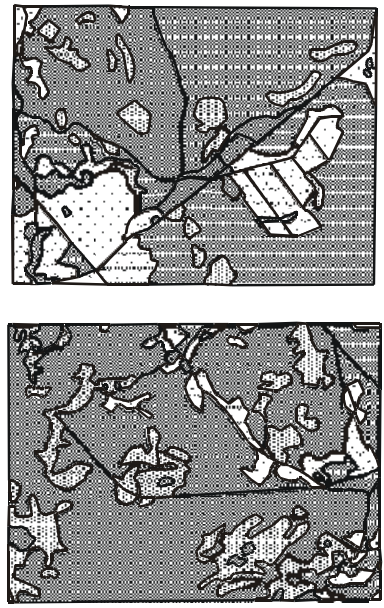

Torgu

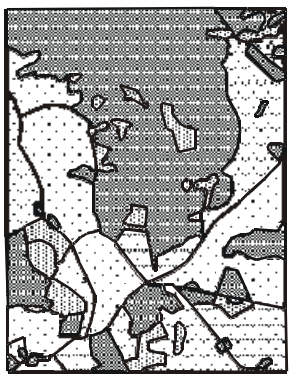

Kihelkonna

Valjala

Fig 2. Land use dynamics in Kihelkonna, Torgu and Valjala sites, Saaremaa in 1900, 1960 and 1990 


\section{Material and methods}

The case study emphasizes visual as well as textual geographical perspectives of representation against the land use changes and population dynamics of Estonia's largest island Saaremaa. Landscape images cannot be regarded as mere visual representations of landscape, rather representations of the political, as well as economic and socio-cultural values of the time period of which the image portrays. The focus of the visual study is on the symbolic imagery of the island and on the dynamics of the imagery. The evolution of socio-cultural values leads to inherent changes in landscape. Therefore, diverse sources, methods and techniques have been used to study historical and contemporary perspectives of landscape's representational dynamics. For the initial step to trace the reasons and background for changes in the representation of the Saaremaa Island during the 20th century we have used a historical narrative overview of the socio-economic conditions of Saaremaa on the basis of scientific literature. The same approach has been used to introduce the central themes in landscape painting of Saaremaa. Kjeldstadli (1999) defines historical narrative approach as a chronological presentation of events. The narrative mediates what has happened in the past, and tries to explain how one situation or state of affairs has led to another (Sedgwick, 1999; O'Leary, 2004). White (1980: 10) argues that every narrative is constructed "on the basis of a set of events which might have been included but were left out." This notion leads to the thought that every historical narrative has a desire to moralize the events of which it treats (White 1980). Jones emphasizes (2003: 27) "this approach contrasts to consciously theory-informed approaches common in the social sciences, whereby events are structured according to whether and how they correspond with or diverge from theories, laws and concepts."

The synopsis of scientific literature from the 1920-1930s shows Saaremaa as a well defined territorial complex which was of particular interest in the heydays of regional studies among Estonian born scientists from disciplines covering a wide range of research issues starting from geology, economics, ethnology and anthropology. ${ }^{2}$ At the same time, scientific texts are a part of historical narrative, being scientists' representation of their experienced reality. As Daugstad (2000) has noted, the scientific texts are - similar to painters' representations or travel descriptions - a part of historical narrative, being scientists' representations of the experienced reality. The analyzed sources also give us an understanding as to what issues the scientists regarded as being important to study as well as to write about in those days. Therefore, studies on Saaremaa conducted by various scientists in the 1920-1930s were analyzed by using historical narrative approach in this project as a socially constructed documentation of socioeconomic conditions, as well as source material for a context analysis of landscape change.

The nature and people of islands have always been an inspiration for artists all over the world. In that sense Saaremaa is not an exception - the island has been and still is stimulating for artists, with its coastal motives characteristic to Saaremaa. The paintings depicting the island have helped to construct the conception of representations about Saaremaa. The paintings for the study have been selected by going through art history books, painters' collections as well as the collection of Estonian Art Museum. As there have been numerous painters working on Saaremaa, conventionally only the most significant ones have been selected in accordance with Estonian art critics and art historians. Similar to the study of scientific research, historical narrative approach was adopted to analyze the themes depicted on the paintings.

The painters' ideas on Saaremaa landscapes have influenced the forming of the imagery ever since the $19^{\text {th }}$ century, including the popular imagery of today. Good material for studying the imagery is published popular landscape photos that provide a commensurate corpus, spanning a long time period and thus enabling the search for discursive patterns and transitions (Häyrynen, 1998). Albers \& James (1988) emphasize that as a form of meaning, photography is the primary medium through which people relate to visual images and make them their own. Once a picture is seen and filtered through the human symbolic system, it is externalized once again in the act of making other pictures and in the act of selecting what to see. In that sense, mass-produced travel photographs are especially influential arbitrators of sight and knowledge. In subtle as well as obvious ways, these photographs not only formulate and institutionalize

\footnotetext{
2 The language of science in Estonia before 1920s was dominantly German and researchers conducting the studies were more often than not Baltic German.
} 
what the local inhabitants as well as the tourists see and how they see it, but also the way they know and understand what they see. At the same time, the images in coffee table books and tourism materials provide a sound corpus for investigating the dynamics of the visual representations.

All 14 tourist brochures and travel guides published in Estonian, Swedish, English and Finnish between 2002 and 2004 either on Saaremaa or Estonia have been analyzed. Both texts and images have been studied. Also, the recommended highlights of Saaremaa presented in the Estonian official tourism website have been studied. In comparison to tourism brochures we analyzed travel guides as they present more detailed information about the places worthy of visiting. The guides are readers friendly oriented with somewhat diverse interests such as car tourists, bicycle tourists or tourists having a specific interest in culture. The coffee table books, on the other hand, are to introduce the remarkable, peculiar as well as ordinary places of the country. All 35 coffee table books and booklets presenting Estonia (28) and Saaremaa (7) have been studied from different time periods. The data set consists of 601 photos, 210 photos found in Estonian albums and 391 photos in the books about Saaremaa. The photos are divided into three historical periods: 1) popular imagery until the World War II; 2) Soviet popular imagery, and 3) popular imagery in 1990-2004. Having that in mind, the main sights and attractions that could give the overview over how Saaremaa is thematically depicted were listed in both types of materials, i.e. tourism brochures and coffee table books, and therefore these materials can be analyzed altogether as one corpus. To analyze the corpus, content analysis of images, as proposed by Rose (2007), has been used. For that, the images are categorized, coded and after that interpreted according to the frequency of the images. This method has also been suggested by Albers \& James (1988) as one way to generate these references in the case of analyzing images is to organize the pictures around focal themes. A focal theme not only includes the kind of subject that is at the centre of a picture but also its essential identifying properties. In doing that we must bear in mind that in marking focal themes, these should not merely be associated with a particular frequency and clustering of appearances.

To discuss the relationship between the imagery vs. reality in landscape planning the thematic county plan Identification of valuable landscapes carried out in 1999-2003 has been used as a baseline data. The county planning Valuable landscapes aims, among other goals, at identifying national landscapes - landscapes that have strong peculiarity and would be regarded as peculiar/unique on local and county levels, as well as in the nationwide context (Palang et al. forthcoming). Studying these landscapes in Saare County gives a wider perspective as to what is considered as characteristic on Saaremaa, and hence different from the rest of Estonia. On the basis of the opinions of different stakeholders the selected areas can be interpreted as the 'official' 'unique' imagery of Saaremaa. The planning process involved experts, local people, county administration and local authorities. The identified areas can be seen as having certain privileges before others as they would need special management care. County planning has been studied by adapting discourse analysis and looking at the thematic discourses.

\section{Results}

The analysis of materials with historical narrative approach reveals that the shaping of visual landscape imagery of Saaremaa began with the Baltic-German landscape paintings of the 19th century and the paintings of Estonian artists from the beginning of the 20th century. In the first half of the 20th century, the island became popular among Estonian painters who in the wave of national romantic movement were in search for themes that would represent the wilderness and the past - intact beaches, harsh open landscape, and the archaic lifestyle. After WWII, Saaremaa became a territory with restricted access due to its geographical location in the Soviet Union. Despite the limited possibilities of access the painters found their way to Saaremaa. Often, in Soviet times and especially in the late 20th century, paintings of coastal people and villagers in everyday action portrayed the struggle with the harsh weather and barren landscape of the island, thereby suggesting tight reliance on nature and land. Saaremaa has been a favorite destination among Estonian landscape painters. No other region of Estonia has been painted as much as Saaremaa. The reasons behind it could be the archaic themes, backwardness of lifestyle in the first half of the 20th century, and flat openness as well as nature 
itself that might inspire painters. It is believed that there exists some sort of specific light on the coasts of Saaremaa - on a sunny summer day the shallow sea, covered with fucus, and the reflection from it creates a light that is peculiar to Saaremaa.

The second part of the representational analysis involved content analysis of visual landscape representations. The results allow suggesting that pictorial landscape representations of Saaremaa in tourism materials, coffee table books and landscape paintings share common features: seascapes, open coastal landscapes with juniper shrubberies, and pastoral idyll with old farmhouses and windmills being the dominant themes on these photos and paintings. Nevertheless, some themes are more characteristic to specific socio-political periods. During the two decades of Estonian independence before WWII, the didactic objective of these books was to show not only what was outstandingly picturesque but also the vernacular landscapes and everyday rural practices of village life on the island. Farm architecture and village patterns acquired a rather significant position in the visual definition of Saaremaa. Contrastingly, in the Soviet imagery two equally prevailing themes existed side by side - that of the socio-economic progress in a peripheral region, and that of an idyllic rural life tracing back to past. The focal themes in Soviet-time albums were seasides and seascapes, as well as depictions of the Soviet heroic past. The cliffs, open coastal meadows abounding in junipers, fishermen at sea as well as bare beaches allowed the reader to take an illusionary mental journey to the seascapes even though they were hardly accessible for laypeople due to the border zone restrictions. Progress, the myth making Soviet propaganda's instrument, was captured in photos of WWII monuments, new residential multi-storey bloc house districts in the countryside, industries, and collective farming, all with the goal of creating a positive image of the Soviet regime. The optimism of Soviet success in turning rural areas into urban-like environments must have had an intention to infect every reader to believe in a brighter future - Communism. The Soviet propaganda seemed to be a compulsory component in the picture books, since through them one reached wider audiences in promoting the Soviet ideology both in Estonia and across borders. In present-day picture books, Saaremaa is depicted as a place of an idyllic and tranquil aura and unspoiled rural landscape. This timeless touch is strengthened by the portrayal of decay and abandonment on photos of old farmhouses and windmills some of which are about to finish their existence. Additionally, the pictures of medieval churches with stone fences in the background evoke abandonment as these places seem to belong to landscape of the past rather than to people's lives today. Equally much represented are the town of Kuressaare and the castle.

Thirdly, we conducted content analysis to find out the focal topics of travel guides. We will discuss these central themes that outline the image of Saaremaa presented to potential domestic as well as foreign visitors today by noting the elements that are used to popularize Saaremaa and introduce its uniqueness. Travel guides tend to idealize the rurality in the island, attributing it the appearance and old-fashioned pace of agricultural pre-WWII Estonia and a way of bringing forward its peculiarity is through historical as well as rural perspectives, as Estonia. The Bradt Travel Guide vividly depicts "Both horses and windmills maintain their role in agriculture, and traffic lights and cats-eyes are still unnecessary" (Taylor, 2002: 191). As the latter example demonstrates, the emphasis on authenticity and traditionalism may sometimes end up with a textual representation which in reality does not exist. When counting the frequency of the places mentioned in the tourism materials, the results (presented by frequency) involved images of windmills, the Kaali meteorite crater, and Kuressaare castle as well as photos of coastline, old farmhouses, women in national costumes, and juniper shrubberies.

Intriguingly, the historical narrative approach reveals that the admired archaic lifestyle of Saaremaa's residents has been conversely defined as backwardness and poverty in reports by researchers in the 1930s. The reasons for that lie mainly in three factors: poor soils, slow land consolidation process and the consequences brought along by WWI. Additionally, Lust (2001) suggests that the backwardness of the island was to some extent caused by geographical isolation and the meagre possibilities for communicating with the mainland of Estonia. Socioeconomic studies (Berg, 1927; Kesanurm \& Talvist, 1938; Käsebier, 1933; Neggo, 1921) inform that Saaremaa was in many ways one of the most left behind regions compared with other counties of Estonia. 


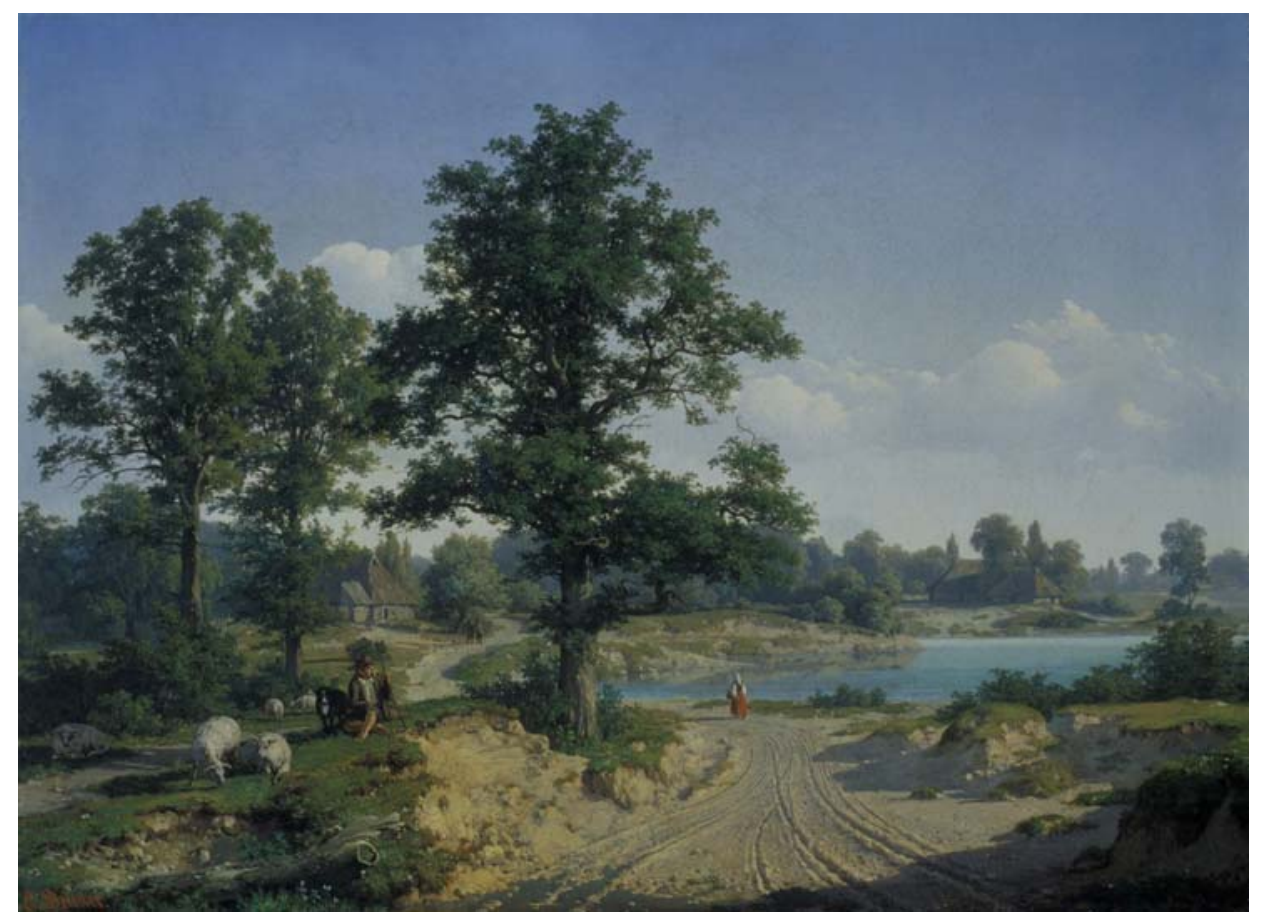

Fig 3. E.G. Dücker Landscape of Saaremaa (1860) (EKM M: M52)

The results of the thematic county plan Identification of valuable landscapes of Saaremaa indicate the nostalgia toward past, as essential part of most of the identified sites feature what was everyday in the landscape in the past - coastal meadows and pastures, patches of wooded meadows, old village structures, open views of seaside and rural areas. The criteria used in defining the valuable landscapes included old landscape structure, historical rural scenes, open views of fields, meadows and coast. With regard to the desired landscape openness it is worth mentioning that all arable land of the county with existing or potential usage value is automatically categorized as valuable landscape in Saaremaa.

\section{Discussion}

The four step analysis of scientific literature, landscape painting, pictorial representations of coffee table books, tourism brochures and theme plan Valuable landscapes point out that the overall Saaremaa visual imagery is constructed on the past- the imagery has remained to a great extent unchanged over the course of 140 years and it has visually been depicted like the painting from the middle of the 19th century, as seen in Figure 3 . The current pictorial representation is retrospective rather than 'a true to life' description of today, offering today a concept of Saaremaa as national open-air museum (sensu Linnap, 2003). This idyllic rural image, originally promoted by the Baltic German amateur painters, has its origins in the mid1800 s. However, the study of scientific texts from the 1930s shows that survival on this island environment was a struggle at best, and one of resignation and surrender (by leaving the island) at worst, in which all available resources were used to the highest degree. This land exploitation resulted in an ordered, at times outsourced landscape, which is perceived today as aesthetically pleasing. People today admire something that in reality was created and dominated by uttermost poverty and misery.

When comparing, the visual imagery of Saaremaa with that of the physical landscape today, then the contemporary reality of the island's physical appearance is a wooded island where agriculture has a minimal role (see for visual illustration Figure 4). The Soviet period forestation, demographic changes, agricultural reforms and policies in the 1990s are some of the reasons that have brought along change in land use, the majority of former meadows and fields are over-grown with forest or bushes. Moreover, besides the large scale changes, changes in the visual appearance of the landscape are traced in details such as disappearance of wind-mills, farmhouses, fishing huts etc. As an effect, the quality of visual landscape representations would not satisfy the expectations of local people and tourists (see for similar discussion Tveit et al., 
2006). A common search for nostalgia towards past landscapes as something attractive constitutes a distinct part of landscape ideal.
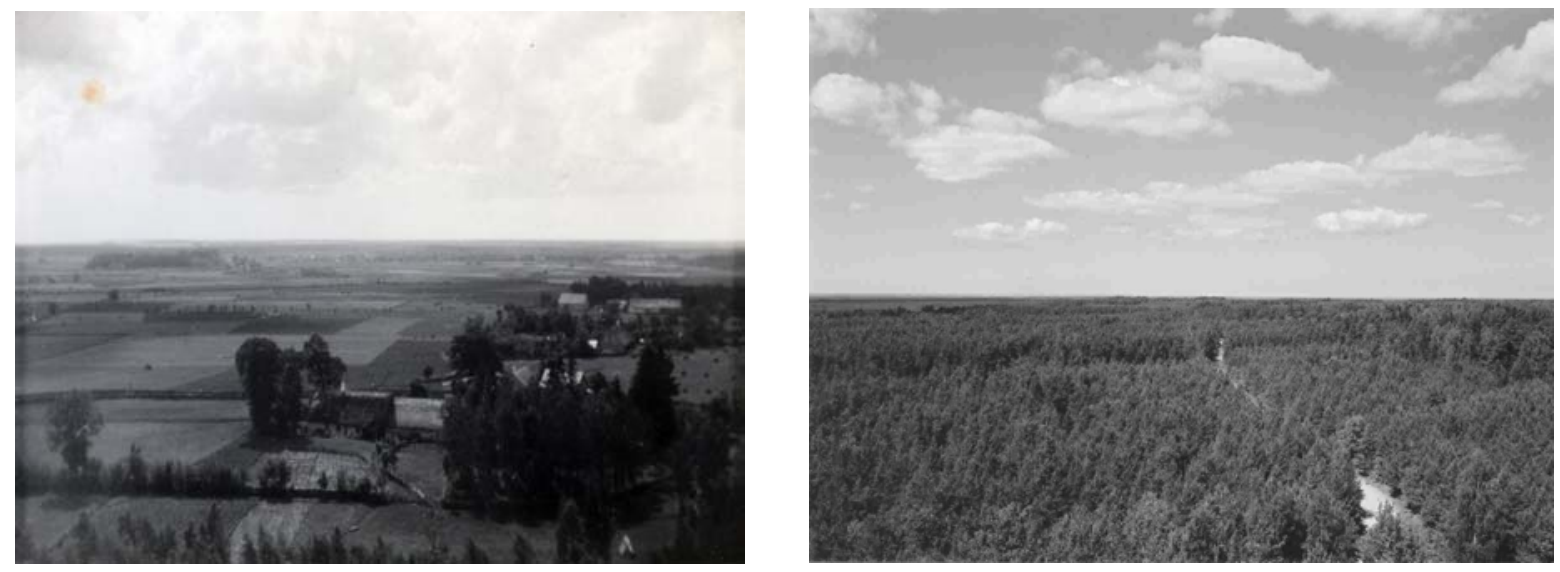

Fig 4. Competing images of Saaremaa Island. To the left, the rural idyllic image as promoted in popular tourism brochures, 1930s. Photo: author unknown (SMF 3761: 127), to the right an overview of the island photographed from above in 2004. Photograph by Helen Sooväli.

Olwig (2004) raises a question of the interrelationship between landscape as physical entity and as representation. According to our study the interrelationship is in the case of Saaremaa Island evident, however a one-way causal relationship. The human psyche seeks for what was in the past, on the other hand expecting steps forward with landscape providing many sights to go and amenities to use. Inevitably, for that, the public presentation of history as heritage is highly selective, emphasizing 'positive', romantic and heroic aspects and ignoring or repressing darker features of the past. Cosgrove (2006) has explained that the public representation of history in landscapes as heritage is selective. The capacity of a region to exploit its past in ways that it appears meaningful and satisfying to contemporary residents, as well as to investors and tourists is widely recognized as a major competitive advantage for places and regions seeking to attract capital. Luckily, the pastoral past of Saaremaa, still strongly anchored in the common memory, is admired both by islanders and outsiders.

Fabricated imagery lives a life of its own parallel to reality. To conclude, in many respects this nostalgia-driven imagery perceived as ideal has rather little to do with the historic reality, and thus the actual social and economic conditions have only a peripheral connection to landscape imagery construction and creation. However, these representations become cultural features gradually and influence the way people apprehend the landscape.

\section{Acknowledgements}

This paper has been supported by the Estonian Science Foundation grant No 6856, Estonian Ministry of Education target-financed project no SF0130033s07 Landscape Practice and Heritage and from the European Union through the European Regional Development Fund (Center of Excellence CECT).

References

[1] AKBAR, K. F., HALE, W. H. G. \& HEADLEY, A. D. (2003). Assessment of scenic beauty of the roadside vegetation in northern England, Landscape and Urban Planning. 63 (3), 139144.

[2] ALBERS, P. C. \& JAMES, R. J. (1988). Travel photography. A methodological approach. Annals of Tourism Research. 15, 134-158.

[3] ASSMUTH, L. (2001). On the margin, at the center: a view from a northern European periphery, in: Assmuth, L. \& Kelam, A. (Eds) The Baltic Sea Islands of Estonia: A Periphery in Transition. 9-18. Tallinn: Estonian Academy Publishers. 
[4] BERG, T. (Ed) (1927) Saaremaa majanduslik elu. Kuressaare: Saaremaa Kirjastus-Ühisus.

[5] CASTREE, N. \& MCMILLAN, T. (2004). Old news: representation and academic novelty, Environment and Planning, A .36, 469-480.

[6] CLAVAL. P. (2004). The Languages of Rural Landscapes, in: Palang, H., Sooväli, H., Antrop, M. \& Setten, G. (Eds) European Rural Landscapes. Persistence and Change in a Globalising Environment. 11-41 Dordrecht: Kluwer Academic Publishers.

[7] GALLENT, N. \& ANDERSSON, J. (2007). Representing England's Rural-Urban Fringe, Landscape Research. 32, 1-21.

[8] COSGROVE, D.E. (1998). Cultural Landscapes, in: Unwin, T. (Ed) A European Geography, pp. 65-81 Harlow: Longman.

[9] COSGROVE, D. E. (2003). Landscape: ecology and semiosis, in: Palang, H. \& Fry, G. (Eds) Landscape Interfaces. Cultural Heritage in Changing Landscapes. 15-21 Dordrecht: Kluwer Academic Publishers.

[10] COSGROVE, D. E. (2006). Landscapes of the cultural space economy: L.A. and the Italian cittá diffusa, in: Terkenli, T. S \& d'Hauteserre, M.-A. (Eds) Landscapes of a New Cultural Economy of Space. 69-91 Amsterdam: Springer.

[11] COSGROVE, D. E. (2006). Geography and Vision. Seeing, imagining and representing the world. London: I.B. Tauris.

[12] DAUGSTAD, K. \& GRYTLI, E. (1999). How to study and manage a multihistoric landscape?, Norsk Geografisk Tidskrift - Norwegian Journal of Geography. 53, 85-92.

[13] DAUGSTAD, K. (2000). Mellom romantikk og realisme. Om seterlandskapet som ideal og realitet. Dr. polit. avhandling. Trondheim: Geografisk Institutt, Norges teknisknaturvitenskapelige universitet.

[14] DORRIAN, M. \& ROSE, G. (2003). Introduction, in: Dorrian, M., Rose, G. (Eds) Deterritorialisations... Revisioning Landscapes and Politics. 12-22 London \& New York: Black Dog Publishing Limited.

[15] Eesti STATISTIKAAMETI REGIONAALNE ANDMEBAAS (2001). available at http://pub.stat.ee/px-web.2001/dialog/statfilere.asp

[16] EGOZ, S., BOWRING, J. \& PERKINS, H. (2001). Tastes in tension: form, function, and meaning in New Zealand's farmed landscapes, Landscape and Urban Planning. 57 (3-4), 177-196.

[17] HÄYRYNEN, M. (1998). Finnish landscape imagery and the construction of the national image. In: Nordehaug, A. (Ed) Nordisk landskapsseminar Sogndal 1996. Rapport nr. 7, pp. 19-31.

[18] GREGORY, D., JOHNSTON. R. J., PRATT, G., WATTS, M. \& WHATMORE, S. (Eds) (2000) The Dictionary of Human Geography, 5th Edition. Oxford: Wiley-Blackwell.

[19] JONES, M. (1991). The elusive reality of landscape. Concepts and approaches in landscape research, Norsk Geografisk Tidsskrift - Norwegian Journal of Geography. 45, 229-244.

[20] JONES, M. (2003). The concept of cultural landscape: discourse and narratives, in: Palang, H. \& Fry, G. (Eds.) Landscape interfaces. Cultural heritage in changing landscapes, 21-53 Dordrecht: Kluwer Academic Publishers.

[21] JONES, M. (2004). Tycho Brache, Cartography and Landscape in 16th Century Scandinavia, in: Palang, H., Sooväli, H., Antrop, M. \& Setten, G. (Eds) European Rural Landscapes. Persistence and Change in a Globalising Environment. 209-227 Dordrecht: Kluwer Academic Publishers.

[22] KÄSEBIER, A. (1933). Saaremaa majandusolud, Riigi Põllutöö-katsejaama toimetused IV Tartu: Eesti Kirjanduse Selts. 
[23] KAUR, E., PALANG, H. \& SOOVÄLI, H. (2004). Landscapes in Change - Opposing Understandings and Valuations, Landscape and Urban Planning. 67 (1-4), 109-120.

[24] KEISTERI, T. (1990). The study of change in cultural landscapes, Fennia. 168 (1), 31-115.

[25] KESANURM, J. \& TALVIST, E. (1938). Eesti saarte sotsiaalolustik ja tegelased Tartu: Autorite Kirjastus.

[26] KJELDSTADLI, K. (1999). Fortida er ikke hva den en gang var. En inføring i historiefaget, 2. utgave Oslo: Universitetsforlaget.

[27] LINNAP, P. (2003). Pictorial Estonia, in: Sarapik, V. \& Tüür, K. (Eds) Koht ja Paik. Place and Location III. Proceedings of the Estonian Academy of Arts. 14, 433-444.

[28] LUST, K. (2001). Talude päriseksostmine Saaremaa eramõisas aastatel 1905-1915. Acta et Commentationes Archivi Historici Estoniae. 7 (14), 109-143 Tartu: Tartu University Press.

[29] MAANDI, P. (2005). Change and Persistence in a Reformed Landscape. A geographical analysis of land reforms and landscape change in Muhu and Rapla municipalities, Estonia, c. 1840 to 2003. Doctoral dissertation. Geografiska Regionstudier, 64.Uppsala Universitet.

[30] MAANDI, P. (2009). The silent articulation of private land rights in Soviet Estonia: A geographical perspective. Geoforum. 40, 454-464.

[31] MARKSOO, A. (2002). Rahvastik ja asustus, in: Kään, H., Mardiste, H., Nelis, R. \& Pesti, O. (Eds.) Saaremaa. Loodus. Aeg. Inimene, 377-464 Tallinn: Eesti Entsüklopeediakirjastus.

[32] MITCHELL, D. (2002). Cultural landscapes: the dialectical landscape - recent landscape research in human geography, Progress in Human Geography. 26 (3), 381-389.

[33] NEGGO, V. (1921). Maaküsimus Saaremaal Tallinn: Üleriiklise Põllumeeste Esitluse Wäljaanne.

[34] O'LEARY, Z. (2004). The essential guide to doing research. London: Sage Publications.

[35] OLWIG, K. R. (2004). 'This is not a landscape': Circulating reference and land shaping, in: Palang, H., Sooväli, H., Antrop, M. \& Setten, G. (Eds) European Rural Landscapes. Persistence and Change in a Globalising Environment. 41-67 Dordrecht: Kluwer Academic Publishers.

[36] PALANG, H. (1993). Mentaalsed maastikud. BSc thesis, Institute of Geography, University of Tartu.

[37] PALANG, H., MANDER, Ü. \& LUUD, A. (1998). Landscape diversity changes in Estonia, Landscape and Urban Planning. 41 (3-4), 163-169.

[38] PALANG, H., ALUMÄE, H. \& MANDER, Ü. (2000). Holistic aspects in landscape development: a scenario approach, Landscape and Urban Planning. 50, 85-94.

[39] PALANG, H., ALUMÄE, H., PRINTSMANN, A, REHEMA M., SEPP, K. \& SOOVÄLISEPPING, H (forthcoming). Social Landscape: ten years of planning 'valuable landscapes' in Estonia. Land Use Policy.

[40] PLANEERINGUD (2004). at http://www.envir.ee/planeeringud/maakond.html

http://www.pria.ee/uudised/150_kiviaedade_taastajat_saavad_pria_It_toetust.html

[41] READ, M. (2005). Planning and the Picturesque: A Case Study of the Dunedin District Plan and its Application to the Management of the Landscape of the Otago Peninsula, Landscape Research. 30, 337-359.

[42] RIPPON, S. (2004). Historic Landscape Analysis. Deciphering the countryside. York: Council for British Archaeology.

[43] ROSE, G. (2007). Visual Methodologies. An Introduction to the Interpretation of Visual Materials. $2^{\text {nd }}$ ed. London: Sage Publications. 
[44] SEDGWICK, P. (1999). Narrative, in: Edgar, A., Sedgwick, P. (Eds.) Key Concepts in Cultural Theory. London: Routledge.

[45] SETTEN, G. (2001). Farmers, planners and the moral message of landscape and nature, Ethics, Place and Environment. 4 (3), 220-225.

[46] SETTEN, G. (2002). Bonden og landskapet. Historier om natursyn, praksis og moral i det jærske landskapet, Dr. polit.-avhandling. Geografisk Institutt, Norges teknisknaturvitenskapelige universitet.

[47] SOOVÄLI, H., PALANG, H., KAUR, E., PEIL, T. \& VERMANDERE, I. (2003). Combining Approaches in Landscape Research. The Case of Saaremaa, Estonia, in: Palang, H. \& Fry, G. (Eds) Landscape Interfaces. Cultural Heritage in Changing Landscapes (pp. 357-375), Dordrecht: Kluwer Academic Publishers.

[48] TAYLOR, N. (2002). Estonia. The Bradt Travel Guide. $3^{\text {rd }}$ ed. Bucks: Bradt Travel Guides Ltd.

[49] TVEIT, M., ODE, Á. \& FRY, G. (2006). Key Concepts in a Framework for Analysing Visual Landscape Character, Landscape Research. 31, 229-257.

[50] WHITE, H. (1980). The Value of Narrativity in the Representation of Reality, in: Mitchell, W.J.T. (Ed.) On Narrative. Chicago: The University of Chicago Press.

[51] WIDGREN, M. (2004). Can Landscapes Be Read?, in: Palang, H., Sooväli, H., Antrop, M. \& Setten, G. (Eds) European Rural Landscapes. Persistence and Change in a Globalising Environment (pp. 455-467). Dordrecht: Kluwer Academic Publishers. 